\title{
Sensory profile of fermented milk drink with yellow mombin (Spondiasmobin L.) and the addition of (Crotonblanchetianus Baill) essential oil
}

\author{
Daiane Gonçalves DOS SANTOS ${ }^{1}$, Edvaldo Mesquita BELTRÃO FILHO², George Rodrigo Beltrão DA CRUZ², \\ Aécio Melo DE LIMA, Max Rocha QUIRINO², Solange DE SOUSA ${ }^{3}$, Neila Lidiany RIBEIRO ${ }^{4 * ~(D) ~}$
}

\begin{abstract}
The study aimed to evaluate the influence of Crotonblanchetianus Baill essential oil on the sensory parameters of fermented milk drinks with yellow mombin pulp. The milk drinks analyzed contained milk and whey from goat origin, water-soluble soy extract, yellow mombin pulp, and Crotonblanchetianus Baill essential oil (CBEO) in the following proportions: 0.0, 0.0035; 0.0070 , and $0.0105 \mathrm{~g} / \mathrm{L}$ according to the Artemia salina toxicity test. The extraction of essential oil from the Crotonblanchetianus Baill leaves was carried out using hydrodistillation by steam. The sensory profile of the fermented milk drink was obtained through Quantitative Descriptive Analysis. The CBEO influenced the color of yellow mombin, brightness, viscosity, woody flavor, appearance, and flavor attributes. The samples were also approved in the acceptance test, with no statistical difference between treatments. Therefore, it was concluded that the addition of CBEO promoted changes in the sensory characteristics of the fermented milk drink with yellow mombin pulp for the appearance and flavor attributes. However, it did not negatively influence the acceptance of the analyzed product.
\end{abstract}

Keywords: volatile compounds; acceptance test; sensory analysis; dairy product.

Practical Application: The current concern of the industry is to develop new products with fewer chemical products, such as preservatives, in their formulation. This fact has led the food industry to seek alternative compounds to achieve its goals related to the microbial stability of its final products to the action of microorganisms that cause deterioration and/or diseases carried by food.

\section{Introduction}

The consumer market is very exigent. It looks for foods with functional properties, changing their eating habits, selecting low fat, sugar, salt, cholesterol, and low chemical additives. Because of this, food industries that are committed to health promotion and disease prevention have developed technologies for the production of functional and safe food for consumption (Baldissera et al., 2011; Ribeiro et al., 2013; Lima et al., 2020).

Functional food is a new market trend. Among products of dairy origin, yogurts (Beltran et al., 2018; El-Shafei et al., 2020; Hadjimbei et al., 2020) and fermented milk drinks (Mituniewicz-Malek et al., 2019) stand out. Furthermore, dairy beverages with added fruit are receiving considerable attention from the consumer market since they are tasty and have high nutritional value (Moreira et al., 2010). Among the fruits that present potential use for the dairy beverage industry is yellow mombin (Spondiasmobin L.) (Borges et al., 2009), a fruit native to the Northeastern Semi-Arid region of Brazil with excellent characteristics related to taste, aroma, and appearance.
The current concern of the industry is to develop new products with fewer chemical products, such as preservatives, in their formulation. This fact has led the food industry to seek alternative compounds to achieve its goals related to the microbial stability of its final products to the action of microorganisms that cause deterioration and/or diseases carried by food (Ribeiro et al., 2013). Due to the industry's growing interest in replacing synthetic or chemical preservatives with natural preservatives, the possibility of using essential oils as a mechanism for food preservation arises. Crotonblanchetianus Baill is widely distributed in the Northeast and Southeast regions. Still, little is reported in the literature about the influence of Croton essential oil on the sensory characteristics of foods (Silva et al., 2010).

The sensory acceptability must be considered when including essential oil since the effectiveness of essential oils in vitro is often much more significant than in food (Witkowska et al., 2014). Therefore, if high concentrations are necessary to achieve the desired activities, unacceptable levels of taste and aroma might be perceived. 
For that, we can use an analytical sensory evaluation, which is a test to the consumer, to obtain reliable, valuable, and more significant information about the quality and acceptability of food. During the development of an innovative production process, information is always urgent. A quantitative descriptive analysis (QDA) is one of the most sophisticated tools that provides a multidimensional sensory "image" of a product and can be helpful during sample comparisons (Mituniewicz-Malek et al., 2019). It is not valid to eliminate contaminants from a food product to obtain a product with an unpleasant taste, aroma, and color since sensory analysis is an essential and fundamental tool for the food industry (Pflanzerr et al., 2010). Because of these aspects, the study aimed to evaluate the influence of Crotonblanchetianus Baill essential oil on the sensory parameters of the fermented milk drink with yellow mombin pulp.

\section{Materials and methods}

\subsection{Experiment location and animals}

This project was submitted to the Animal Use Ethics Committee (CEUA) of the Federal University of Paraíba and approved according to protocol No. 052/2017. The experiment was conducted at the Federal University of Paraíba, Campus at Bananeiras- Paraíba, Brazil (altitude 552 m, latitude 6 $41^{\prime} 11^{\prime \prime}$, longitude $\left.35^{\circ} 37^{\prime} 41^{\prime \prime}\right)$. The air temperature was $24.97^{\circ} \mathrm{C}$, and relative humidity was $76.48 \%$ in the stalls.

Twelve Saanen multiparous goats weighing $40 \pm 6 \mathrm{~kg}$ and $30 \pm$ five days of lactation were used. The animals were kept in a confinement system for 60 days, housed in a covered shed, and kept in individual pens made of wood, provided with feeder and drinker.

\subsection{Crotonblanchetianus Baill essential oil}

The essential oil was extracted from the Crotonblanchetianus Baill leaves collected in municipalities of Solânea, Brejo microregion of Paraiba state, Brazil. The altitude is $626 \mathrm{~m}$, located between the geographical coordinates $6^{\circ} 48^{\prime} 30.1^{\prime \prime}$ south latitude and $35^{\circ} 44^{\prime} 48^{\prime \prime}$ longitude, west of Greenwich, with a hot and humid climate.

The species was identified by the botanist Dr. Leonardo Pessoa Felix and was cataloged and registered at the Herbarium Jayme Coelho de Moraes, Department of Botany, located at the Center of Agricultural Sciences Federal University of Paraíba, under the registration number 23.217. The essential oil extraction from the Crotonblanchetianus Baill leaves was obtained through hydrodistillation on a laboratory scale by steam dragging. After this process, the essential oil was stored in a glass bottle wrapped in aluminum foil and kept under refrigeration.

\subsection{Preparation of the milk drink and treatments}

For the production of the milk drink, milk of caprine origin was used, originated from the Goat laboratory of CCHSA/UFPB. Goat milk whey came from the processing of regional fresh cheese. The yellow mombin pulp and soybeans were obtained from a supermarket in the region of Bananeiras, Paraíba. Salt, sucrose and Streptococcus thermophilus, and Thermobacterium bulgaricum lactic acid bacteria were also used.

The obtaining of the hydro-soluble Soy Extract was carried out manually. First, the cleaning and selection of the soybeans were carried out before obtaining the water-soluble extract. Water was added to the cleaned grains and then boiled for 5 minutes. Then, they were washed under running water. More water was added. They were submitted to a second boiling, after which the beans were ground, and then cooked for 10 minutes after boiling. The mixture was then filtered and cooked for another 10 minutes. Finally, salt and sucrose were added, and the mixture was ready for later homogenization (Mituniewicz-Malek et al., 2019).

The milk drink was obtained according to the methodology of Macêdo et al. (2011). First, whey was collected and heated. Next, sucrose was added ( $10 \mathrm{~g} / 100 \mathrm{~g}$ of the volume of milk, or mixture of milk and whey), pasteurized at $95^{\circ} \mathrm{C}$ for 5 minutes. Then all the ingredients were added, sucrose at a content of $8 \mathrm{~g} / 100 \mathrm{~g}$, yellow mombin pulp at a concentration of $10 \mathrm{~g} / 100$ grams, and the Crotonblanchetianus Baill essential oil according to the treatments (Table 1).

Crotonblanchetianus Baill essential oil was added to the milk drink. A completely randomized design was used with four levels of oil addition $(0.00 ; 0.0035 ; 0.0070$, and 0.0105$)$ repeated three times.

Lactic bacteria were added to the same tank where the mixture was. After adding the culture, it was left standing at $45^{\circ} \mathrm{C}$ for 4 to 5 hours. After this period of fermentation, the clot formed was broken by stirring. Thus the homogenization and breaking of the curd occurred, giving the milk drink a semiliquid texture. Cooling and homogenization occurred shortly after coagulation, and then the temperature was kept below $10^{\circ} \mathrm{C}$. Cooling is necessary to keep the milk drink from becoming excessively acidic, spoiling the product's flavor. In addition, it prevents undesirable microbial growth.

Table 1. Percentage of ingredients for the processing of goat milk milky drink with Crotonblanchetianus Baill essential oil.

\begin{tabular}{ccccc}
\hline Ingredient & \multicolumn{5}{c}{ Crotonblanchetianus Baill essential oil (g L-1) } \\
\cline { 2 - 5 } & 0.00 & 0.0035 & 0.0070 & 65 \\
\hline Milk (\%) & 65 & 65 & 20 & 65 \\
Soro (\%) & 20 & 20 & 15 & 20 \\
Hydro-soluble soy extract (\%) & 15 & 15 & 8 & 105 \\
Sucrose (g 100 g $\left.{ }^{-1}\right)$ & 8 & 8 & 10 & 8 \\
Pulp (g 100 g $\left.\mathrm{g}^{-1}\right)$ & 10 & 10 & 10 \\
\hline
\end{tabular}




\subsection{Physical-chemical analysis}

Dairy beverages were evaluated in triplicates. The freshly prepared fermented dairy beverage samples were evaluated for protein content, lipids, ash, moisture, titratable acidity (\% lactic acid), sugars and $\mathrm{pH}$ according to the methods of the AOAC (Association of Analytical Chemists, 2010). The activity water (Aw) was determined using the Aqualab Lite equipment (BrasEQ Brasileira de Equipamentos Ltda., Jarinu, SP, Brazil).

The lactose (\%) were evaluated according to the Master Complete $^{\oplus}$ Milk Analyzer (AKSO ${ }^{\circledR}$, São Leopoldo, Rio Grande do Sul, Brasil), under specific technical conditions

The samples' color was determined using a Delta Vista Spectrophotometer, Vista $450 \mathrm{G}$ delta model, with a threedimensional color diagram $\left(L^{*}, C^{*}, h\right)$, in which $L^{*}$ indicates luminosity and $\mathrm{C}^{*}$ indicates $\mathrm{C}$ Chroma, indicating color saturation. In addition, $\mathrm{h}$ indicates the hue angle, a value in degrees in the three-dimensional color diagram: $0^{\circ}$ (red), $90^{\circ}$ (yellow), $180^{\circ}$ (green), and $270^{\circ}$ (blue).

\subsection{Microbiological analysis}

According to the recommendations of RDC Resolution No. 12, January 2, 2001 (Brasil, 2001), the samples were analyzed according to the methodology described by the American Public Health Association (2001) to determine total coliforms, thermotolerant coliforms, viable aerobic mesophilic bacteria, coagulase-positive Staphylococcus, and Salmonella sp. The analyses of total and thermotolerant coliforms were performed following the technique of the most probable number. The analysis of viable aerobic mesophilic bacteria was performed by the depth plate technique using Plate Count Agar and incubation at $35 \pm$ $2{ }^{\circ} \mathrm{C}$ for a period of $48 \mathrm{hr}$. Coagulase-positive Staphylococcal analyses were performed by direct plate counting. The plates were incubated in an oven at $36{ }^{\circ} \mathrm{C}$ for $48 \mathrm{hr}$, and then the plates were collected to count the colonies. For the analysis of Salmonella sp. the procedure was as follows: a pre-enrichment of the samples with lactose broth and incubation at $42 \pm 2{ }^{\circ} \mathrm{C}$ for $24 \mathrm{hr}$ was carried out, and then a selective enrichment with Tetrionate and Selenite cystine broth followed by incubation in xylose lysine deoxycholate Agar and Enteric Agar was performed (Lima et al., 2020).

\subsection{Sensory analysis}

APPROVED Research Protocol (No. of Opinion: 1,942,748) by the Ethics Committee for Research on Human Beings of CEPCCM/UFPB, at an Ordinary Meeting held on February 22, 2017.

Sensory analysis was performed at the Laboratory of Product Performance and Sensory Analysis at the UFPB. In all tests, samples were randomly placed in trays with randomized three-digit codes. In addition, the milk drink was submitted to sensory evaluation using Quantitative Descriptive Analysis (Stone \& Sidel, 2004). The samples were divided into equal portions of $20 \mathrm{ml}$ polystyrene plates, marked with a random 3 -digit code. The samples were presented to panel members in different positions to avoid the possible effects of the order of presentation (MacFie et al., 1989).

Sensory analysis was performed in individual booths with controlled environmental conditions of around $23^{\circ} \mathrm{C}$ (International Organization for Standardization, 1988). The evaluation was conducted with nine consumers, men and women, including untrained students, being selected based on the interest and habits of consuming goat dairy products. The age range of the consumers was 18 to 25 years. The tests took place in 4 sessions and nine trained tasters. First, consumers evaluated the milk drink samples. Next, they were asked to mark the option that best suited the product concerning overall acceptance using a 9-point unstructured hedonic scale (Barbosa et al., 2016; Cardello, 2017). Next, the tasters described how they liked or disliked the attributes: odor, appearance, flavor, and texture (Table 2). Finally, a scale of 5 points recommended by Meilgaard et al. (2007) was used to evaluate the intention of purchasing: 1 (Certainly I would buy it); 2 (Probably I would buy it); 3 (Maybe I would

Table 2. Definitions of descriptor terms for the samples of milky fruit pulp of Caja with Crotonblanchetianus Baill essential oil.

\begin{tabular}{|c|c|}
\hline \multirow{2}{*}{ Descriptor } & Definition \\
\hline & Appearance \\
\hline yellow color Caja & The intensity of the yellow color is characteristic of milky products with cajá flavor. \\
\hline Shine & Ability to reflect light on the surface of the product \\
\hline \multirow[t]{2}{*}{ Viscosity } & Drainage time at the edge of the body \\
\hline & Odour \\
\hline Spondiasmobin L. & The characteristic odor of fruit. \\
\hline Goat milk & The intensity of the characteristic odor of goat milk. \\
\hline \multirow[t]{2}{*}{ Fermented } & Odor intensity is associated with the growth of milk cultures that produce volatile substances in the final product. \\
\hline & Flavor \\
\hline Wood & The flavor associated with wood \\
\hline Goat milk & The intensity of the characteristic flavor of goat milk. \\
\hline Spondias mombin L. & The characteristic flavor of Spondiasmobin L in natura \\
\hline \multirow[t]{2}{*}{ Acid } & It describes the primary taste produced by aqueous solutions of acidic substances such as lactic acid solutions. \\
\hline & Texture \\
\hline Consistency & Flow resistance property in the mouth \\
\hline Astringency & A substance that produces the sensation of "tying the mouth." \\
\hline
\end{tabular}


buy it/Maybe I would not buy it); 4 (Probably I would not buy it) and 5 (Certainly I would not buy it).

\subsection{Statistical analysis}

Data were subjected to analysis of variance (ANOVA), and the Tukey test compared the mean at 5\% probability using GLM of the SAS ${ }^{\circledast}$ program. For sensorial analysis, the mathematical model was: $Y_{\mathrm{ijk}}=\mu+T_{\mathrm{i}}+\mathrm{e}_{\mathrm{i} \mathrm{j}, \mathrm{k}}$, where $\mathrm{Y}_{\mathrm{ijk}}$ is the dependent variable, $\mu$ is the mean, Ti is the fixed effect of the treatment at $i$ levels from 1 to 4 , and $e_{i \mathrm{ik}}$ is the error. The Ryan-Einot-Gabriel-Welsch test at a significance level of 5\% was used for sensory analysis. Finally, data were submitted to regression analysis, at a 5\% error probability, performed with the REG procedure of the software SAS (2001).

\section{Results}

In the physical-chemical analysis of the milk drink with the addition of Crotonblanchetianus Baill essential oil (Table 3), it is observed that there was a linear effect for lipids, protein, and lactose and a quadratic effect for $\mathrm{pH}$. Furthermore, the variables of $\mathrm{pH}$, lipids, and protein showed a significant effect $(\mathrm{P}<0.05)$ with the inclusion of the essential oil.

With the addition of the Crotonblanchetianus Baill essential oil in the milk drink, there was a linear decreasing effect for lactose. As the essential oil increased, there was a reduction in this parameter from 2.66 to $2.20 \mathrm{~g} / 100 \mathrm{~g}$. Thus, a significant decrease was also observed for the $\mathrm{pH}(\mathrm{P}<0.005)$ with the Crotonblanchetianus Baill essential oil from 6.27 to 6.13 in the milk drink with a higher essential oil level.

With the addition of the Crotonblanchetianus Baill essential oil in the milk drink, there was an increasing linear effect $(\mathrm{P}<0.05)$ in the lipid levels, varying from 1.71 to $2.13 \%$, an increase of
$0.42 \%$. The same happened for protein; however, this increase was only $0.02 \%$.

The color measurements had a significant effect $(\mathrm{P}<0.05)$ with the inclusion of the Crotonblanchetianus Baill essential oil (Table 3). As the proportion of Crotonblanchetianus Baill essential oil increased, the value of $\mathrm{L}^{*}$ also increased, from $36.77 \%$ to $49.21 \%$ in the milk drink, with the more significant addition of essential oil color became lighter. In addition, it is observed that the values of $\mathrm{a}^{*}$ and $\mathrm{b}^{*}$ were positive towards red and yellow, respectively, which may have occurred due to the addition of the essential oil, which has a slightly yellow color, to the yellow mombin pulp, and also to the water-soluble soy extract, which positively influenced the color intensity of the milk drink.

It was observed that as the Crotonblanchetianus Baill essential oil was added, there was a significant increase $(\mathrm{P}<0.005)$ in the parameters of chroma and hue. The $\mathrm{c}^{*}$ indicating color saturation increased from 13.09 to 15.60 with $0.0105 \mathrm{~g} / \mathrm{L}$ of Crotonblanchetianus Baill essential oil. Furthermore, for the hue parameter, there was an increase from 82.38 to 86.17 in the highest level of Crotonblanchetianus Baill essential oil addition in the milk drink, indicating that the essential oil caused an increase in the tonality of the samples, predominantly yellow and red.

As for microbiological analyses, no microbial growth was observed in the milk drink with increasing Crotonblanchetianus Baill essential oil (Table 4).

The attributes of appearance (brightness $(\mathrm{P}=0.008)$ and viscosity $(P=0.043))$ and woody flavor $(P<.0001)$ showed a significant difference with the inclusion of Crotonblanchetianus Baill essential oil (Table 5).

It was found that the treatments without, with 0.0035 , and with $0.0070 \mathrm{~g} / \mathrm{L}$ of essential oil, obtained the highest averages in

Table 3. Physicochemical composition and cor instrumental of the milk drink with the addition of Crotonblanchetianus Baill essential oil.

\begin{tabular}{|c|c|c|c|c|c|c|c|}
\hline \multirow{2}{*}{ Variable } & \multicolumn{4}{|c|}{ Crotonblanchetianus Baill essential oil $\left(\mathrm{g} \mathrm{L}^{-1}\right)$} & \multirow{2}{*}{ SEM } & \multicolumn{2}{|c|}{$P$-value } \\
\hline & 0.00 & 0.0035 & 0.0070 & 0,0105 & & Linear & Quadr \\
\hline Acidity (\%) & 0.31 & 0.30 & 0.31 & 0.34 & 0.02 & 0.140 & 0.135 \\
\hline $\mathrm{pH}$ & $6.27 \mathrm{a}$ & $6.14 \mathrm{~b}$ & $6.13 b$ & $6.14 \mathrm{~b}$ & 0.01 & 0.005 & $0.0007^{1}$ \\
\hline Sucrose $\left({\left.\mathrm{g} 100 \mathrm{~g}^{-1}\right)}\right.$ & 1.80 & 1.70 & 1.71 & 1.99 & 0.35 & 0.499 & 0.355 \\
\hline Lactose $\left(\mathrm{g} 100 \mathrm{~g}^{-1}\right)$ & 2.66 & 2.39 & 2.20 & 2.27 & 0.21 & $0.036^{2}$ & 0.202 \\
\hline Total sugars (g $\left.100 \mathrm{~g}^{-1}\right)$ & 4.46 & 4.10 & 4.11 & 4.27 & 0.31 & 0.511 & 0.175 \\
\hline Moisture (\%) & 81.75 & 81.85 & 81.80 & 81.81 & 0.15 & 0.712 & 0.585 \\
\hline Ash (\%) & 1.51 & 1.58 & 1.54 & 1.50 & 0.16 & 0.838 & 0.542 \\
\hline Fat $(\%)$ & $1.71 \mathrm{~b}$ & $2.02 \mathrm{ab}$ & $2.05 \mathrm{ab}$ & $2.13 \mathrm{a}$ & 0.15 & $0.010^{3}$ & 0.240 \\
\hline Protein (\%) & $2.08 \mathrm{~b}$ & $2.09 \mathrm{ab}$ & $2.10 \mathrm{ab}$ & $2.11 \mathrm{a}$ & 0.007 & $0.001^{4}$ & 0.423 \\
\hline $\mathrm{Aw}(\%)$ & 0.99 & 0.99 & 0.99 & 0.99 & 0.003 & 0.692 & 0.829 \\
\hline \multicolumn{8}{|l|}{ Instrumental color } \\
\hline$L^{*}$ & $36.77 \mathrm{c}$ & $33.49 \mathrm{~d}$ & $40.14 b$ & $49.22 \mathrm{a}$ & 0.010 & $0.001^{5}$ & 0.396 \\
\hline$a^{*}$ & $1.73 b$ & $2.12 \mathrm{a}$ & $0.96 c$ & $1.04 \mathrm{c}$ & 0.021 & 0.171 & 0.140 \\
\hline $\mathrm{b}^{*}$ & $12.97 \mathrm{~d}$ & $13.19 c$ & $13.93 b$ & $15.76 \mathrm{a}$ & 0.012 & 0.0001 & $0.002^{6}$ \\
\hline Croma & $13.09 \mathrm{~d}$ & $13.36 \mathrm{c}$ & $13.96 \mathrm{~b}$ & $15.61 \mathrm{a}$ & 0.014 & 0.0001 & $0.006^{7}$ \\
\hline Hue & $82.19 b$ & $80.83 \mathrm{~b}$ & $85.55 \mathrm{a}$ & $86.17 \mathrm{a}$ & 0.374 & 0.071 & 0.120 \\
\hline
\end{tabular}

Different letters on the line differ by Tukey's test at the $5 \%$ probability leve; $\mathrm{SEM}=$ standar error means; Quadr. $=$ quadratic; ${ }^{1} \mathrm{Y}=6.26-40.62 \mathrm{x}+2789.12 \mathrm{x}^{2}\left(\mathrm{R}^{2}=0.89\right) .{ }^{2} \mathrm{Y}=2.58-38.56 \mathrm{x}$ $\left(\mathrm{R}^{2}=0.37\right) .{ }^{3} \mathrm{Y}=1.79+37.05 \mathrm{x}\left(\mathrm{R}^{2}=0.50\right) .{ }^{4} \mathrm{Y}=2.09+2.10 \mathrm{x}\left(\mathrm{R}^{2}=0.64\right) .{ }^{5} \mathrm{Y}=36.33+123.45 \mathrm{x}\left(\mathrm{R}^{2}=0.86\right) .{ }^{6} \mathrm{Y}=12.88+144.01 \mathrm{x}-1110.52 \mathrm{x}^{2}\left(\mathrm{R}^{2}=0.99\right) .{ }^{7} \mathrm{Y}=13.03+130.79 \mathrm{x}-1012.29 \mathrm{x}^{2}\left(\mathrm{R}^{2}=0.99\right)$. 
Table 4. Microbiological evaluation of milk drink with the addition of Crotonblanchetianus Baill essential oil.

\begin{tabular}{|c|c|c|c|c|}
\hline \multirow{2}{*}{ Microorganisms } & \multicolumn{4}{|c|}{ Crotonblanchetianus Baill essential oil $\left(\mathrm{g} \mathrm{L}^{-1}\right)$} \\
\hline & 0,00 & 0,0035 & 0,0070 & 0,0105 \\
\hline Coliform $45^{\circ} \mathrm{C}(\mathrm{MPN} g-1)$ & $<3.0$ & $<3.0$ & $<3.0$ & $<3.0$ \\
\hline Staphylococcus spp. (CFU g-1) & $<100$ & $<100$ & $<100$ & $<100$ \\
\hline Salmonella sp. (25 g) & Absent & Absent & Absent & Absent \\
\hline
\end{tabular}

Table 5. Sensory evaluation of milk drink with the addition of Crotonblanchetianus Baill essential oil.

\begin{tabular}{|c|c|c|c|c|c|c|c|}
\hline & \multirow{2}{*}{ Descriptor } & \multicolumn{4}{|c|}{ Crotonblanchetianus Baill essential oil $\left(\mathrm{g} \mathrm{L}^{-1}\right)$} & \multirow{2}{*}{ SEM } & \multirow{2}{*}{ P-value } \\
\hline & & 0.00 & 0.0035 & 0.0070 & 0.0105 & & \\
\hline \multirow[t]{3}{*}{ Appearance } & Yellow Spondiasmobin L & 7.86 & 7.37 & 7.38 & 7.30 & 0.58 & 0.137 \\
\hline & Shine & $5.16 \mathrm{~b}$ & $5.23 \mathrm{~b}$ & $6.05 \mathrm{a}$ & $6.02 \mathrm{a}$ & 0.73 & 0.008 \\
\hline & Viscosity & $4.78 \mathrm{a}$ & $4.43 \mathrm{~b}$ & $4.06 \mathrm{ab}$ & $3.88 \mathrm{~b}$ & 0.73 & 0.043 \\
\hline \multirow[t]{3}{*}{ Odor } & Spondias mombin $\mathrm{L}$. & 5.01 & 5.33 & 5.22 & 4.69 & 0.97 & 0.475 \\
\hline & Goat & 3.56 & 3.39 & 3.36 & 3.52 & 1.14 & 0.974 \\
\hline & Fermented & 2.85 & 2.72 & 2.79 & 3.29 & 0.84 & 0.431 \\
\hline \multirow[t]{4}{*}{ Flavor } & Wood & $1.39 \mathrm{c}$ & $3.64 \mathrm{~b}$ & $5.17 \mathrm{a}$ & $4.84 \mathrm{a}$ & 0.91 & $<.0001$ \\
\hline & Goat & 3.56 & 3.39 & 3.36 & 3.52 & 0.65 & 0.877 \\
\hline & Spondias mombin L. & 6.22 & 6.87 & 6.07 & 6.11 & 0.91 & 0.180 \\
\hline & Acid & 2.07 & 1.94 & 2.55 & 2.65 & 0.83 & 0.172 \\
\hline \multirow[t]{2}{*}{ Texture } & Consistency & 5.17 & 5.07 & 5.62 & 5.71 & 0.80 & 0.209 \\
\hline & Adstringency & 2.64 & 2.87 & 2.77 & 2.49 & 0.99 & 0.841 \\
\hline \multicolumn{2}{|c|}{ Global acceptance } & 7.23 & 7.07 & 7.04 & 7.00 & 0.70 & 0.891 \\
\hline
\end{tabular}

SEM = Standard error means; Means followed by different lowercase letters in the same row indicate significant differences according to the Ryan-Einot-Gabriel-Welsch test at a $5 \%$ significance level.

the color attribute, $7.86,7.37$, and 7.38 , respectively. On the other hand, the milk drink with the highest essential oil level obtained the lowest average (7.30). It probably happened because the presence of the essential oil gave the milk drink a more intense yellow color than the other treatments and did not represent the yellow mombin color. Furthermore, as the essential oil was added, the viscosity attribute decreased from 4.78 to 3.88 .

For the woody descriptor, it was found that as the Crotonblanchetianus Baill essential oil was added to the fermented milk drink with yellow mombin pulp, there was an increase in the woody flavor identified by the tasters. Without the essential oil, the median score was 1.39 . With its insertion, the average was 5.17 at the level of $0.0070 \mathrm{~g} / \mathrm{L}$ of Crotonblanchetianus Baill essential oil. Therefore, all treatments would be well accepted in the market since they presented marks above 7.0 regardless of the Crotonblanchetianus Baill essential oil, which did not influence the acceptance of the product by the tasters.

\section{Discussion}

Lactic acid bacteria (Lactobacillus and Streptococcus) have a particular aptitude for producing lactic acid from the conversion of lactose. The result of this process is the lowering of the $\mathrm{pH}$ in the food. However, the samples of milk drinks were not acidic $(0.31 \%)$. Therefore, they were below the recommendation of the legislation for fermented milk (Brazil, 2007), favoring the process of conversion and the reduction of lactose in the product, and thus resulting in a decrease in the $\mathrm{pH}$ (Kassa et al., 2014; Gonçalves et al., 2018).
Because the essential oil is an oily and fat-soluble substance, its addition to the product caused an increase in the lipid content (Simões et al., 2007). Legislation determines 2.0\% lipids (Brazil, 2005) for milk drinks, without specifying the category. The milk drink without the addition of essential oil was below that recommended level. Protein contents follow the limits established by the current legislation, which is a minimum of $1.0 \%$. The values of protein obtained ranged from 2.08 to $2.10 \%$, indicating good adequacy. These values are considered satisfactory for the product.

Other studies have proven Crotonblanchetianus Baill essential oil to have antimicrobial activity (Silva et al., 2010). Supposedly, during the manufacturing of this milk drink, the addition of the Crotonblanchetianus Baill essential oil before the inoculation of the lactic bacteria caused a reduction in the metabolic activity of the lactic bacteria, mainly for lipids and protein. In addition to that, the $\mathrm{pH}$ was much below other fermented products, which are generally a little acidic. The same can be seen in Silva et al. (2018), who carried out $\mathrm{pH}$ measurements from the beginning until the end of the production of fermented milk drinks with yellow mombin, soursop, and tamarind pulp and observed an initial $\mathrm{pH}$ of 6.54 . However, after 5 hours of fermentation, it reached 4.67 .

The reduction of free water can explain lower $L^{*}$ values due to increasing total solids and less light reflection (GarcíaPérez et al., 2005). According to legislation, the ideal coloring of milk drink is white or according to the food ingredients and/or dyes added (Brasil, 2005). Since yellow mombin pulp, 
water-soluble soy extract, and Crotonblanchetianus Baill essential oil was added to the milk drink, it became yellowish. Yellow mombin pulp and water-soluble soy extract vary from yellow to orange. With the addition of the essential oil, the color tone was intensified, which contributed positively to the visual aspect of the milk drink.

Microbiological results are following legislation for milk drinks (Brasil, 2005). All milk drink samples indicate acceptable hygienic-sanitary quality throughout production and storage processes and demonstrate microbiological quality required by the current legislation, so all samples were fit for consumption and within the reference values for this type of product.

The intense shine in the milk drink with the higher level of essential oil may have occurred due to the addition of the essential oil itself, which has a slightly yellow color, the yellow mombin pulp, and also the water-soluble soy extract, which all influenced the color intensity of the product. According to Bermúdez-Aguirre et al. (2010), the color is related to the visual aspect of the product, which can determine the acceptability or rejection of a product, making this attribute very valuable for the food industry.

The viscosity of the milk drink is explained because the molecules that make up the essential oils are smaller and lighter, and less viscous (Navarrete et al., 2011).

Guedes Neto et al. (2003) reported that lower concentrations of total solids could cause low viscosity in milk drinks by insufficient heat treatment and homogenization, incorrect mixing, and the gel being destroyed during acidification by the type of lactic culture, and by too low incubation temperature. Besides this, the chemical composition, the concentration, the size and shape of the molecules in suspension, the conformations in the solvent, and the oscillations between the bonds formed. In addition, the number of intramolecular and intermolecular collisions can also influence the viscosity of solutions (Buffo \& Reineccius, 2002).

According to Santos et al. (2013) the presence of tannins and steroids for C.blanchetianus. Phenolic compounds have an antioxidant function, prevent or delay lipid oxidation in foods, and maintain their nutritional qualities (Danesi et al., 2008).

The woody flavor can be explained by the oil used in the treatments extracted from a shrub plant. Essential oils are natural substances and are often responsible for the specific flavor of the plants. These oils play an essential role in the food industry as flavorings, improving the organoleptic qualities of the products (Simões et al., 2007). This led to the woody flavor of the milk drink.

The sensory impact must be considered when using essential oils in food. For example, if high oil concentrations are required to achieve the desired activities, this might be perceived in the sensory testing (Hsieh et al., 2001; Nazer et al., 2005; Gutierrez et al., 2008). An analytical sensory evaluation and consumer testing provide reliable, valuable, and the most meaningful information on the quality and acceptability of food. During the development of an innovative production process, information is always urgent. A quantitative descriptive analysis
(QDA) is one of the most sophisticated tools that provides a multidimensional sensory 'image' of a product and could be helpful during the comparison of samples (Ferrão et al., 2018; Mituniewicz- Malek et al., 2019). QDA qualifies the type and quantifies the intensity of sensory properties immediately after sensory stimulation (Stone \& Sidel, 2004).

Ribeiro et al. (2020) evaluated the fermented yellow mombin juice using Lactobacillus acidophilus NRRL B-4495 and concluded that the juice formulation without fermentation was the most accepted (64.7\%). Even so, this acceptance was considered low $(<70.0 \%)$. On the other hand, the 16-hour fermented juice formulation had the lowest acceptance rate (36.5\%). The lower acceptance percentages found for fermented formulations may be linked to the fact that fermentation changes the common sensory characteristics of the juice through the production of metabolites.

\section{Conclusions}

Adding $0.0035,0.0070$, and 0.0105 of Crotonblanchetianus Baill essential oil altered the brightness and viscosity attributes and added a woody flavor to the fermented milk drink with yellow mombin pulp. The evaluators well accepted the product.

\section{References}

American Public Health Association - APHA. (2001). Standard methods for the examination of waste and wastewater (18th ed.). Washington: APHA/AWNA/WEF.

Association of Analytical Chemists - AOAC. (2008). Official methods of analysis of AOAC International (19th ed., 1219 p.). Washington: AOAC International.

Association of Analytical Chemists - AOAC. (2010). Official methods of analysis of AOAC International (19th ed., 1219 p.). Washington: AOAC International

Baldissera, A. C., Betta, F. D., Penna, A. L. B., \& Lindner, J. D. (2011). Alimentos funcionais: uma nova fronteira para o desenvolvimento de bebidas protéicas a base de soro de leite. Semina: Ciências Agrárias, 32(4), 1497-1512. http://dx.doi.org/10.5433/1679-0359.2011v32n4p1497.

Barbosa, I. C., Oliveira, M. E., Madruga, M. S., Gullón, B., Pacheco, M. T., Gomes, A. M., Batista, A. S., Pintado, M. M., Souza, E. L., \& Queiroga, R. C. (2016). Influence of the addition of Lactobacillus acidophilus La-05, Bifidobacterium animalis subsp. Lactis Bb-12 and inulin on the technological, physicochemical, microbiological and sensory features of creamy goat cheese. Food \& Function, 7(10), 4356-4371. http://dx.doi.org/10.1039/c6fo00657d. PMid:27711907.

Beltran, M. C., Morari-Pirlog, A., Quintanilla, P., Escriche, I., \& Molina, M. P. (2018). Influence of enrofloxacin on the coagulation time and the quality parameters of goat's milk yogurt. International Journal of Dairy Technology, 71(1), 105-111. http://dx.doi.org/10.1111/14710307.12388.

Bermúdez-Aguirre, D., Yánez, J. A., Dunne, C. P., Davies, N. M., \& Barbosa-Cánovas, G. V. (2010). Study of strawberry flavored milk under pulsed electric field processing. Food Research International, 43(8), 2201-2207. http://dx.doi.org/10.1016/j.foodres.2010.07.021.

Borges, K. C., Medeiros, A. C. L., \& Correia, R. T. P. (2009). Iogurte de leite de búfala sabor cajá (Spondias lutea L.): caracterização físicoquímica e aceitação sensorial entre indivíduos de 11 a 16 anos. Alimentos e Nutrição, 20(2), 295-300. 
Brasil. Ministério da Agricultura, Pecuária e Abastecimento. (2007, October 23). Instrução Normativa $n^{\circ} 46$ de 23/10/2007. Adota o Regulamento Técnico de Identidade e Qualidade de Leites Fermentados. Diário Oficial [da] República Federativa do Brasil.

Brasil. Ministério da Saúde. Agência Nacional de Vigilância Sanitária. (2001, January 02). Regulamento Técnico sobre os padrões microbiológicos para alimentos (Resolução RDC n. 12, de 02 de janeiro de 2001). Diário Oficial [da] República Federativa do Brasil.

Brasil. Ministério de Estado da Agricultura, Pecuária e Abastecimento. (2005, August 23). Instrução Normativa n. ${ }^{\circ} 16 / 00$, de 23/08/00. Regulamento Técnico de Identidade e Qualidade de Bebidas Láctea. Diário Oficial [da] República Federativa do Brasil.

Buffo, R. A., \& Reineccius, G. A. (2002). Modeling the rheology of concentrated beverage emulsions. Journal of Food Engineering, 51(4), 267-272. http://dx.doi.org/10.1016/S0260-8774(01)00067-X.

Cardello, A. V. (2017). Hedonic scaling, assumptions, contexts, and frames of reference. Current Opinion in Food Science, 15, 14-21. http://dx.doi.org/10.1016/j.cofs.2017.05.002.

Danesi, F., Elementi, S., Neri, R., Maranesi, M., D’antuono, L. F., \& Bordoni, A. (2008). Effect of cultivar on the protection of cardiomyocytes from oxidative stress by essential oils and aqueous extracts of basil (Ocimum basilicum L.). Journal of Agricultural and Food Chemistry, 56(21), 9911-9917. http://dx.doi.org/10.1021/ jf8018547. PMid:18928294.

El-Shafei, S. M. S., Sakr, S. S., \& Abou-Soliman, N. H. I. (2020). The impact of supplementing goats' milk with quinoa extract on some properties of yogurt. International Journal of Dairy Technology, 73(1), 126-133. http://dx.doi.org/10.1111/1471-0307.12628.

Ferrão, L. L., Ferreira, M. V. S., Cavalcanti, R. N., Carvalho, A. F. A., Pimentel, T. C., Silva, H. L. A., Silva, R., Esmerino, E. A., Neto, R. P. C., Tavares, M. I. B., Freitas, M. Q., Menezes, J. C. V., Cabral, L. M., Moraes, J., Silva, M. C., Mathias, S. P., Raices, R. S. L., Pastore, G. M., \& Cruz, A. G. (2018). The xylooligosaccharide addition and sodium reduction in requeijão cremoso processed cheese. Food Research International, 107, 137-147. http://dx.doi.org/10.1016/j. foodres.2018.02.018. PMid:295804.

Folch, J., Lees, M., \& Stanley, G. H. S. (1957). A simple method for the isolation and purification of total lipids from animal tissues. The Journal of Biological Chemistry, 226(1), 497-509. http://dx.doi. org/10.1016/S0021-9258(18)64849-5. PMid:13428781.

García-Pérez, F. J., Lario, Y., Fernández-López, J., Pérez-Alvarez, J. A., \& Sendra, E. (2005). Effect of orange fiber addition on yogurt color during fermentation and cold storage. Industrial Apllications, 30(6), 457-463. http://dx.doi.org/10.1002/col.20158.

Gonçalves, S. F., Oliveira, S. P., Souza, K. S. S., Reis, I. M. F., Teixeira, N. T. P., Santos, S. H. S., Brandi, I. V., \& Almeida, A. C. (2018). Poder conservante e atividade antioxidante do óleo essencial de cravo da Índia adicionado em bebida láctea fermentada. In $\mathrm{H}$. $\mathrm{H}$. C. Mello, \& O. Z. Fátima (Eds.), Construindo saberes, formando pessoas e transformando a pecuária nacional: 55a Reunião Anual da Sociedade Brasileira de Zootecnia. Goiânia, Brasil: Sociedade Brasileira de Zootecnia - SBZ.

Guedes Neto, L. G., Fonseca, L. M., \& Souza, M. R. (2003). Defeitos tecnológicos de leites fermentados. Revista Leite e Derivados, 2(74), 29-35.

Gutierrez, J., Barry-Ryan, C., \& Bourke, P. (2008). The antimicrobial efficacy of plant essential oil combinations and interactions with food ingredients. International Journal of Food Microbiology, 124(1), 91-97. http://dx.doi.org/10.1016/j.ijfoodmicro.2008.02.028. PMid:18378032.

Hadjimbei, E., Botsaris, E., Goulas, V., Alexandri, E., Gekas, V., \& Gerothanassis, I. P. (2020). Functional stability of goats' milk yogurt supplemented with Pistacia Atlantica resin extracts and Saccharomyces boulardii. International Journal of Dairy Technology, 73(1), 134-143. http://dx.doi.org/10.1111/1471-0307.12629.

Hsieh, P., Mau, J., \& Huang, S. (2001). Antimicrobial effect of various combinations of plant extracts. Food Microbiology, 18(1), 35-43. http://dx.doi.org/10.1006/fmic.2000.0376.

Instituto Adolfo Lutz - IAL (2008) Métodos físico-químicos para análise de alimentos (4. ed., 1. ed. digital). São Paulo: SES - CCD - IAL. 1020 p.

International Organization for Standardization - ISO. (1993). ISO 85861: sensory analysis, general guidance for the selection, training, and monitoring of assessors. Part 1: selected assessors. Switzerland: ISO.

Al Kassaa, I. A., Hober, D., Hamze, M., Chihib, N. E., \& Drider, D. (2014). Antiviral potential of lactic acid bacteria and their bacteriocins. Probiotics and Antimicrobial Proteins, 6(3-4), 177-185. http://dx.doi. org/10.1007/s12602-014-9162-6. PMid:24880436.

Lima, A. M., Cruz, G. R. B., Costa, R. G., Ribeiro, N. L., Beltrão, E. M. F., Sousa, S., Justino, E. S., \& Santos, D. G. (2020). Physical-chemical and microbiological quality of milk and cheese of goats fed with bi-distilled glycerin. Food Science and Technology (Campinas), 41(1), 25-33. http://dx.doi.org/10.1590/fst.27119.

Macêdo, A. L. B., Beltrão Filho, E. M., Farias, J. T., \& Vitor, I. (2011). Caracterização fisico-quimica de bebida lacteal de origem caprina com adição de extrato hidrossolúvel de soja e polpa de cajá. Caderno verde de agroecologia e desensolvimento sustentável, 1(1). Retrieved from https://www.gvaa.com.br/revista/index.php/CVADS/article/ view/978

MacFie, H. J., Bratchell, N., Greenhoff, K., \& Vallis, L. V. (1989). Designs to balance the effect of the order of presentation and first-order carry-over effects in hall tests. Journal of Sensory Studies, 4(2), 129-148. http://dx.doi.org/10.1111/j.1745-459X.1989.tb00463.x.

Meilgaard, M. C., Carr, B. T., \& Carr, B. T. (2006). Sensory evaluation techniques (4th ed.). Boca Raton: CRC Press. http://dx.doi. org/10.1201/b16452.

Mituniewicz-Malek, A., Zielinska, D., \& Ziarno, M. (2019). Probiotic monocultures in fermented goat milk beverages - the sensory quality of the final product. International Journal of Dairy Technology, 72(2), 240-247. http://dx.doi.org/10.1111/1471-0307.12576.

Moreira, R. W. M., Madrona, G., Bergamasco, R., Pereira, N., \& Branco, I. (2010). Avaliação sensorial e reológica de uma bebida achocolatada elaborada a partir de extrato hidrossolúvel de soja e soro de queijo. Acta Scientiarum, 32(4), 435-438. http://dx.doi. org/10.4025/actascitechnol.v32i4.5739.

Navarrete, A., Wallraf, S., Mato, R. B., \& Cocero, M. J. (2011). Improvement of essential oil steam distillation by microwave pretreatment. I\&EC Research, 50, 4667-4671. http://dx.doi.org/10.1021/Ie102218g

Nazer, A. I., Kobilinsky, A., Tholozan, J. L., \& Dubois-Brissonnet, F. (2005). Combinations of food antimicrobials at low levels inhibit the growth of Salmonella sv. Typhimurium: a synergistic effect? Food Microbiology, 22(5), 391-398. http://dx.doi.org/10.1016/j. fm.2004.10.003.

Ribeiro, D. S., Siqueira, F. G., Velozo, E. S., \& Guimarães, A. G. (2013). Evaluation rosemary essential oil in the control of multidrug-resistant Escherichia coli in Coalho cheese. Journal of Biotechnology and Biodiversity, 4(1), 1-9.

Ribeiro, E. S. S., Damasceno, K. S. F. S. C., Dantas, L. M. C., Azevedo, W. M., Leite, P. I. P., Assis, C. F \& Sousa Junior, F. C. (2020). Fermented yellow mombin juice using Lactobacillus acidophilus NRRL B-4495: Chemical composition, bioactive properties, and survival in simulated gastrointestinal conditions. Plos One, 15(9), e0239392. https://doi. org/10.1371/journal.pone.0239392. 
Santos, L. M. L., Santana, A. L. B. D., Nascimento, M. S., \& Sousa, K. M. (2013). Avaliação do potencial alelopático de croton blanchetianus baill e croton rhamnifolioides pax \& $k$. hoffm. sobre a germinação de lactuca sativa l. Revista de Biologia e Fermácia., 9(1), 27-35.

SAS.(2012). SAS/STAT User's guide. North Caroline: SAS Institute Inc.

Silva, C. F., Soares, P. R., Souza, K. S. S., Almeida, K. R. P. R., Matias, A. D., Barbosa, R. P., Rocha, F. G. S., Souza, S. A., Faria, A. V. S., \& Farias, P. K. S. (2018). Elaboração de bebida láctea adicionada de polpa de fruta de cajá, graviola e tamarindo. Revista Eletrônica Acervo Saúde, 14(14), 1643-1648. http://dx.doi.org/10.25248/REAS350_2018.

Silva, J. S., Sales, M. F., Gomes, A. P. S., \& Carneiro-Torres, D. S. (2010). Sinopse das espécies de Croton L. (Euphorbiaceae) no estado de
Pernambuco, Brasil. Acta Botanica Brasílica, 24(2), 441-453. http:// dx.doi.org/10.1590/S0102-33062010000200015.

Simões, C. M. O., Schenkel, E. P., Gosmann, G., Mello, J. C. P., Mentz, L. A., \& Petrovick, P. R. (2007). Farmacognosia: da planta ao medicamento (6. ed). Porto Alegre: UFSC/UFRGS.

Stone, H., \& Sidel, J. L. (2004). Sensory evaluation practices (3rd ed.). Cambridge: Academic Press.

Witkowska, A. M., Hickey, D. K., \& Wilkinson, M. G. (2014). Effect of Variation in Food Components and Composition on the Antimicrobial Activity of Oregano and Clove Essential Oils in Broth and a Reformulated Reduced Salt Vegetable Soup Product. Journal of Food Research, 3(6), 92-106. http://dx.doi.org/10.5539/jfr.v3n6p92. 